\title{
Composition and abundance of zooplankton community of an impacted estuarine lagoon in Northeast Brazil
}

\author{
Almeida, LR. ${ }^{a, c}$, Costa, IS. ${ }^{b}$ and Eskinazi-Sant'Anna, EM. ${ }^{c *}$

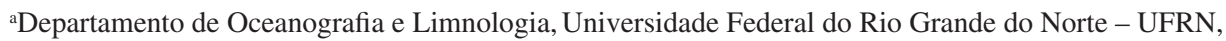 \\ Via Costeira, s/n, Praia de Mãe Luiza, CEP 59014-100, Natal, RN, Brazil \\ ${ }^{\text {b}}$ Departamento de Microbiologia e Parasitologia, Universidade Federal do Rio Grande do Norte - UFRN, \\ Campus Universitário Lagoa Nova, Natal, RN, Brazil \\ 'Departamento de Ciências Biológicas - DEBIO, Instituto de Ciências Exatas e Biológicas - ICEB, \\ Universidade Federal de Ouro Preto - UFOP, Campus Universitário Morro do Cruzeiro, CEP 34500-000, Ouro Preto, MG, Brazil \\ *e-mail: eskinazi@iceb.ufop.br
}

Received October 6, 2010 - Accepted December 16, 2011 - Distributed February 29, 2012

(With 6 figures)

\begin{abstract}
Abastract
Guaraíras Lagoon is a shallow coastal lagoon subject to intense human impacts, including shrimp aquaculture, urban expansion and agricultural activities, and is therefore vulnerable to eutrophication. With the aim of detecting the effects of human-mediated disturbance and environmental change in the lagoon, a spatial-temporal study was conducted in order to assess the actual ecological status of the lagoon and the species composition and density of the mesozooplankton, highlighting copepod assemblages. Algal biomass (chlorophyll- $a$ ) and total phosphorus concentration indicated that the lagoon is a meso-eutrophic coastal system in the inner part, and is oligotrophic in the areas influenced by the marine waters. High salinities were recorded in the lagoon, characterizing the lagoon as a coastal-marine ecosystem, rather than true estuarine. Mesozooplankton abundance fluctuated widely and showed marked spatial heterogeneity. The copepod assemblage was characterized by a coastal/estuarine group dominated by Oithona spp., Acartia lilljeborgi and Parvocalanus crassirostris in the inner areas of the lagoon, and a marine group characterized by the copepods Paracalanus quasimodo, Calanopia americana, Corycaeus (C.) speciosus and Monstrilloida in the area of marine influence. Thus, the spatial variability in the distribution of mesozooplankton species can be ascribed to the presence of a horizontal gradient of salinity and trophic conditions. Overall, the results showed that spatial variation in the water physicochemical characteristics of Guarairas Lagoon have significant effects on the structure and repartition of the mesozooplankton assemblages, which may potentially affect the functioning and biodiversity of this coastal ecosystem.
\end{abstract}

Keywords: estuarine lagoon, anthropogenic impacts, zooplankton, copepods, composition.

\section{Composição e abundância da comunidade zooplanctônica de um laguna estuarina impactada do Nordeste do Brasil}

\section{Resumo}

A laguna de Guaraíras é uma laguna costeira rasa sujeita a intensos impactos humanos, incluindo a carcinocultura, expansão urbana e agricultura, e desta forma, sujeita à eutrofização. Um estudo espaço-temporal foi conduzido com o objetivo de avaliar o status ecológico da laguna e a composição de espécies e densidade do mesozooplâncton, com destaque para a assembleia de copépodos. A biomassa algal (clorofila- $a$ ) e a concentração de fósforo total indicaram que a laguna apresenta condições mesoeutróficas em sua porção interna, e oligotróficas nas áreas sob influência marinha. Foram registradas altas salinidades na laguna, caracterizando a laguna como um sistema costeiro-marinho, ao invés de um ambiente verdadeiramente estuarino. A abundância zooplanctônica flutuou expressivamente, e apresentou uma marcada heterogeneidade espacial. A assembleia de copépodos foi caracterizada por um grupo costeiro-estuarino, dominado por Oithona spp., Acartia lilljeborgi e Parvocalanus crassirostris nas áreas interiores da laguna, e um grupo marinho caracterizado pelos copépodos Paracalanus quasimodo, Calanopia americana, Corycaeus (C.) speciosus e Monstrilloida na área sob influência marinha. Desta forma, a variabilidade espacial na distribuição das espécies zooplanctônicas pode ser atribuída à presença de um gradiente horizontal de salinidade e condições tróficas. De uma forma geral, os resultados mostraram que a variação espacial nas características físicas e químicas da laguna de Guaraíras tem efeitos significativos sobre a estrutura e composição das assembleias zooplanctônicas, as quais podem afetar potencialmente o funcionamento e a biodiversidade deste ecossistema costeiro.

Palavras-chave: laguna estuarina, impactos antrópicos, zooplâncton, copépodos, composição. 


\section{Introduction}

Estuaries are the main transition zones or ecotones between riverine and marine habitats. They are geomorphologically very dynamic and ephemeral systems, influenced both by sea and land changes, forming a complex mixture of many different habitats (Meire et al., 2005; Champalbert et al., 2007). Among these habitats, estuarine lagoons are commonly characterized by high productivity, areas of limited exchange with the adjacent ocean, and function as filters or decanters of materials, thus accumulating nutrients, organic matter, inorganic sediment and contaminants from the rivers, ocean, atmosphere and adjacent land (Kjerfve and Magill, 1989; Lloret et al., 2008).

Perhaps the most distinctive feature that contrasts coastal lagoons with other ecosystems is the nature and variability of the physical and chemical forces that influence them. Many estuarine systems experience widely varying temperatures, salinity, concentrations of chemicals, and plant and animal densities, many of which are mediated by water movement over relatively short time scales (McLusky and Elliott, 2004). Thus, the creation of a continuum in salinity and biogeochemical features is one of the most common patterns in coastal lagoons. These gradients strongly influence the spatial and temporal distribution and abundance of biological assemblages in estuaries.

Human pressure and impact on estuaries are intense, because most urbanization is concentrated in coastal regions. In the Brazilian Northeast, estuarine lagoons are subject to diverse impacts, including landfills, dredging and construction, and changes in depth that modify the hydrodynamics, biodiversity, and goods and services of these important coastal ecosystems (Neumann et al., 1992). On the coast of the state of Rio Grande do Norte, shrimp farming has developed rapidly, increasing by about $20 \%$ per year during the past decade. The input of $\mathrm{N}$ and $\mathrm{P}$ to coastal waters from shrimp farms is estimated as $1.9{\mathrm{t} . \mathrm{km}^{-2} \text {.year }}^{-1}$ (Lacerda et al., 2006). The coastal ecosystems of Rio Grande do Norte are extremely vulnerable to the impacts associated with shrimp production, which include deforestation, the introduction of exotic species and eutrophication.

The combination of natural environmental variability over small spatial scales and the magnitude of pollution sources (e.g., sewage outfalls, aquaculture effluents, river inputs) make coastal lagoons highly heterogeneous in terms of levels of disturbance, pollution and eutrophication. For this reason, the identification and assessment of ecological status and environmental variability may be helpful for the development of good planning and monitoring programs, leading to better management of estuarine ecosystems (Moreno et al., 2008).

The Guaraíras Lagoon is located on the southern coast of Rio Grande do Norte, and is under strong human pressure resulting from shrimp farming, the sugar-cane industry, domestic and hospital wastes and mining activities. The lagoon is situated in a densely populated area with intense economic activity. At present, it is connected to the ocean through a canal approximately $350 \mathrm{~m}$ wide. This feature of the lagoon, which provides free communication with the adjacent ocean, has been permanent since 1942. Prior to that date, the system underwent successive natural changes in its dynamics, with some periods of isolation and others when it was connected to the sea. Despite these multiple environmental changes, studies describing their potential effects on the zooplankton community of Guarairas lagoon are still lacking.

The objective of the present study was to describe spatially and seasonally the composition and abundance of the mesozooplankton assemblages, with emphasis on the copepods, of a coastal lagoon under different flow regimes. Zooplankton is an important link in the energy transfer of organic matter produced by photosynthesis to other trophic levels, as well as including indicator species and providing subsidies for present and past ecological processes (Buskey, 1993; Leandro et al., 2007). In order to assess the variations of the zooplankton due to the environmental characteristics, we analyzed the thermal and salinity patterns and various parameters indicating the trophic state (total phosphorus and chlorophyll- $a$ ). We hypothesized that the permanent link of the lagoon with the sea and the consequently increase in salinity would force the zooplankton community, especially copepod assemblages, towards dominance by marine-coastal species rather than estuarine species and will also influence the trophic conditions of the lagoon. Hence, we address the question of how anthropogenic activities can be important in shaping the zooplankton community of the lagoon.

\section{Material and Methods}

\subsection{Study area}

The state of Rio Grande do Norte in the Brazilian Northeast, especially in the south of the city of Natal has some typical morphological features such as dunes, cliffs, salt pans, riverine-marine plains and coastal ponds. The regional climate is classified as humid tropical, and annually received a rainfall of 1,400 to $1,700 \mathrm{~mm}$, with two distinct seasonal periods of precipitation: a dry season $\left(38.1 \pm 25.7 \mathrm{~mm}\right.$. month $\left.^{-1}\right)$ that normally extends between September and February, and a rainy season $\left(197.7 \pm 54.3\right.$ mm.month $\left.{ }^{-1}\right)$ from March to August.

In this region, about $50 \mathrm{~km}$ south of Natal, lies the Guaraíras Lagoon, which is part of a lagoon complex called the "Complexo Lagunar Estuarino Nísia Floresta-PapebaGuaraíras", consisting of three interconnected lagoons of which Guaraíras is the largest $\left(6^{\circ} 9^{\prime}\right.$ to $6^{\circ} 14^{\prime} \mathrm{S}$ and $35^{\circ} 5^{\prime}$ to $35^{\circ} 10^{\prime} \mathrm{W}$ ) (Figure 1 ). The lagoon is about $7 \mathrm{~km}$ long, and is a shallow estuarine lagoon with depths ranging from 0.5 to $2 \mathrm{~m}$ and up to $11 \mathrm{~m}$ in the narrow channels.

The lagoon is part of the Rio Jacú hydrographic basin, and this river supplies the main inflow of fresh water, in the innermost part of the lagoon. The description of the historical evolution of the morphology of the Guaraíras Lagoon reports that the system underwent successive natural 


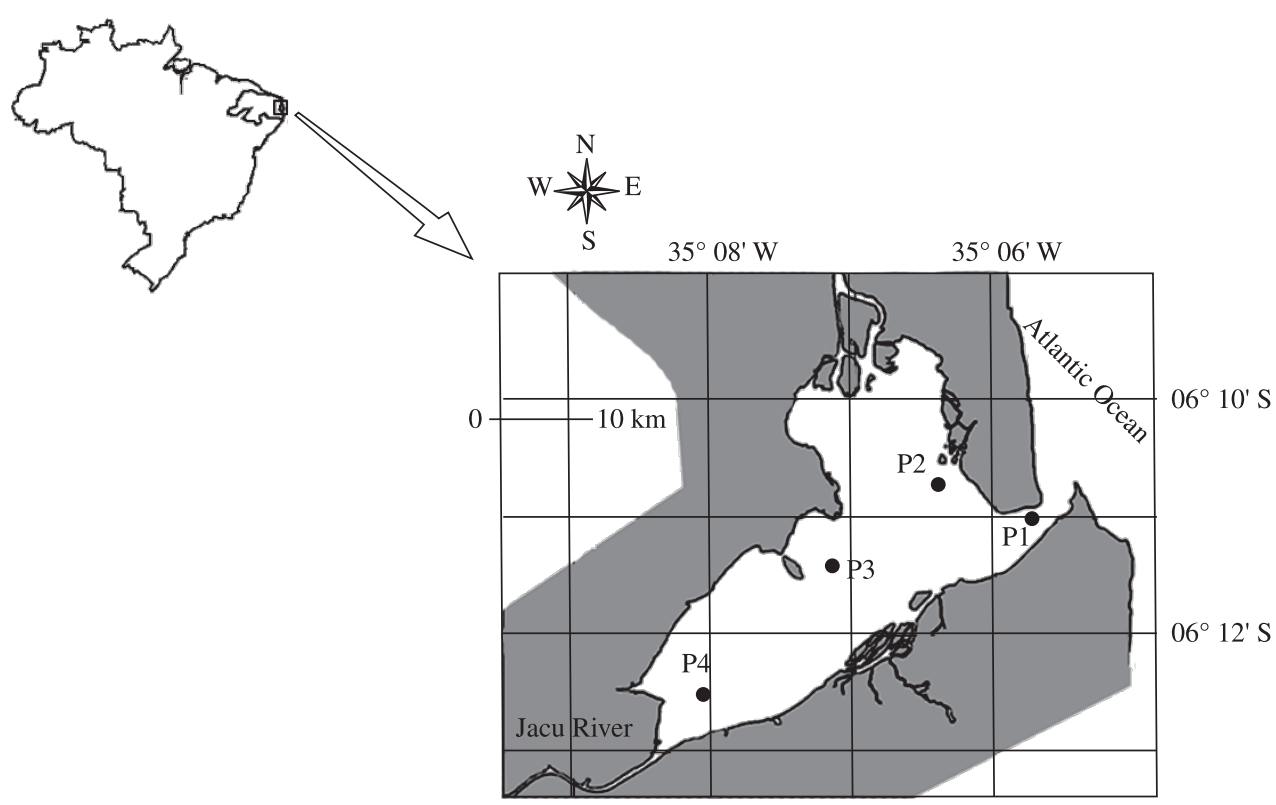

Figure 1. Location of Guaraíras lagoon, indicating sampling points.

changes in its dynamics, with some periods of isolation and others of connection to the sea. In 1923, a narrow canal was opened connecting the lagoon to the sea, with the objective of draining the lake during the rainy season. This canal rapidly widened, permanently linking the lake to the sea. Taking this into account, a lagoon regime was formed, with tidal action.

\subsection{Sampling}

Sampling was undertaken during the rainy season (17 June and 26 July) and dry season (8 November and 9 December) in 2005. These collections were always carried out at high tide, because of the shallowness of the lagoon. The sampling points were defined according to the geomorphology of the lagoon and represent the main environmental conditions in the lagoon (coastal influence, water mixture area and fluvial zone). These points showed the following characteristics: $\mathrm{P} 1\left(06^{\circ} 11^{\prime} 033^{\prime \prime} \mathrm{S}\right.$ and $35^{\circ} 05^{\prime} 602$ " W), channel at the lagoon mouth, strongly influenced by the adjacent coastal region, and about $10 \mathrm{~m}$ deep at high tide; P2 (06 10' 915" S and 35 06' 194" W), near the communication with the Nísia Floresta and Papeba lagoons in the same system of the studied lagoon, with an approximate depth of $3 \mathrm{~m}$ at high tide; P3 (06 $11^{\prime} 511^{\prime \prime} \mathrm{S}$ and $\left.35^{\circ} 07^{\prime} 419^{\prime \prime} \mathrm{W}\right)$, situated in the central part of the lagoon, with a depth of about $5 \mathrm{~m}$; and P4 (06 ${ }^{\circ} 12^{\prime} 493$ " S and $35^{\circ} 08^{\prime} 083^{\prime \prime} \mathrm{W}$ ), the innermost part of the lagoon, influenced by the Jacu River, with a mean depth of $1.5 \mathrm{~m}$ at high tide (Figure 1).

\subsection{Environmental variables}

The water used for the analyses of phosphorous and chlorophyll- $a$ was collected at the subsurface $(0.5 \mathrm{~m})$, using a van Dorn bottle. The water temperature and salinity were measured with a Horiba (U-23) multiprobe. Transparency was measured by means of a Secchi disc (cm). Chlorophyll- $a(\mathrm{Chl}-a)$ was determined by filtering $250 \mathrm{~mL}$ of water through a Whatmann membrane filter $(0.45 \mathrm{~S} \mathrm{~mm})$. Pigments were extracted with $90 \%$ acetone. The concentrations of chlorophyll- $a$ were determined fluorimetrically according to the method described by Holm-Hansen et al. (1965). The determination of total phosphorus followed the methodology of Valderrama (1995).

\subsection{Zooplankton}

Mesozooplankton samples were collected by oblique hauls using plankton nets having two different mesh sizes: 64 and $200 \mathrm{~mm}$, both equipped with a HydroBios flowmeter. All the samples were preserved in a $4 \%$ buffered formalin-seawater solution. For quantitative analysis, 3 subsamples ( $5 \mathrm{~mL}$ each) were obtained from the samples collected with the $64 \mathrm{~mm}$ mesh plankton net. At least 200 individuals of each dominant species were counted. Individuals belonging to less-abundant species were counted in the entire samples. Mesozooplankton samples obtained with the $200 \mathrm{~mm}$ mesh size net plankton were counted completely. Subsamples for counting were analyzed under an Olympus stereomicroscope and mesozooplankton abundance expressed as the number of individuals per cubic meter (ind. $\mathrm{m}^{-3}$ ).

The abundance of mesozooplankton was acquired from the hauls made with the $200 \mathrm{~mm}$ mesh size net plankton, except for Polychaeta larvae and copepodits from Oithona spp., Parvocalanus crassirostris and Euterpina acutifrons, which are typically small (<50 mm). The abundances of these zooplankters were significantly higher in the samples carried out using the $64 \mathrm{~mm}$ mesh 
size net plankton $(t$-test, $\mathrm{p}<0,05)$ and hence considered in the description of their abundance. This methodology, using different sizes of mesh and analyzing mesozooplanktonic data jointly, taking into account the higher abundance values obtained from each pair of samples (200 mm or $64 \mathrm{~mm}$ mesh size net), was also used in others studies on zooplankton composition (Weber and Roff, 1995; Lopes et al., 1998). Copepods were considered as potential biomarkers to verify the environmental conditions of the lagoon (salinity gradient and trophic status) and for this reason, identified to species level.

\subsection{Data analysis}

The hierarchical and multidimensional scaling (MDS) analyses of similarity between stations and copepod species were computed on the basis of the Bray-Curtis similarity index and $\log _{10}(\mathrm{X}+1)$ transformed data. The diversity index $\left(\mathrm{H}_{0}\right)$ and eveness of the copepod population was calculated using the Shannon-Wiener diversity index (Shannon, 1948). The analysis of ordination of principal components (PCA) was also calculated using the log-
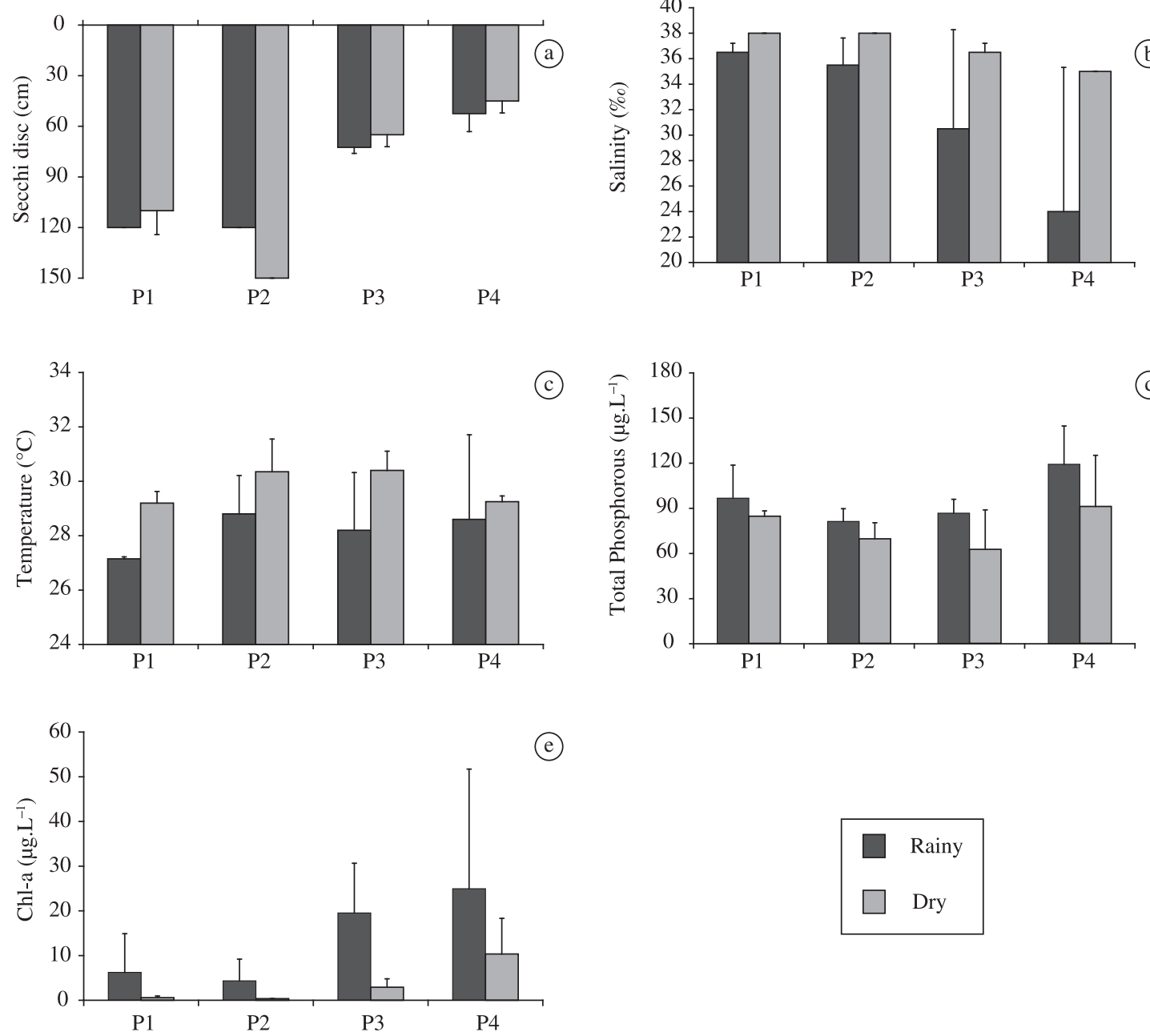

transformed and standardized data for the principal mesozooplankton groups, a species of Copepoda, and environmental parameters, to assess the associations among them. These analyses were carried out using the PRIMER statistical package version 5.0.

\section{Results}

\subsection{Environmental variables}

All the environmental variables of Guaraíras Lagoon are shown in Figure 2. The maximum water transparency was always observed at the sampling points under marine influence (P1 and P2), with Secchi values $>100 \mathrm{~cm}$. The lowest values were recorded in the zone of river influence (P3 and P4), with Secchi values $<75 \mathrm{~cm}$. The water temperature did not vary seasonally $(t$-test, $\mathrm{p}<0.05)$, with a mean of $28.2^{\circ} \mathrm{C}( \pm 0.74)$ in the rainy season, and $29.8^{\circ} \mathrm{C}$ $( \pm 0.66)$ in the dry season. A clear salinity gradient was observed, with a large increase in salinity from $\mathrm{P} 4$ (riverine zone) to $\mathrm{P} 1$ (coastal zone) $(t$-test, $\mathrm{p}<0.05)$. For the entire

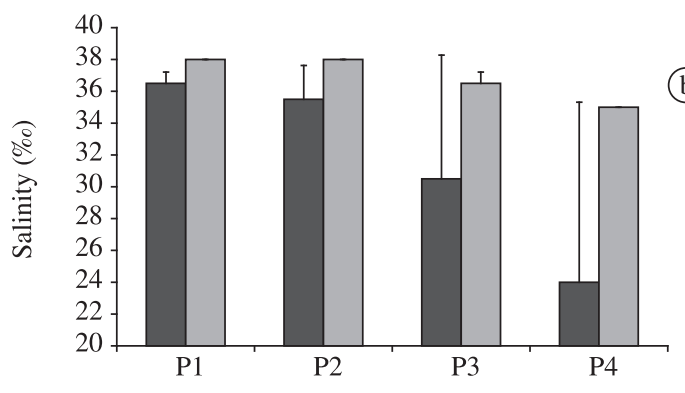

(b)

Figure 2. Spatial and temporal variation of mean concentration (mean \pm SD) of water transparence (Secchi disc) (a), temperature (b), salinity (c), total phosphorus (d) and chlorophyll- $a$ (e) in Guaraíras lagoon. 
study period, the mean salinity of the lagoon was quite high $(34.3 \pm 4.8)$. Total phosphorus concentration in the water was high, with the absolute maximum recorded at $\mathrm{P} 4$ $(136.9 \mathrm{mM})$ and a marked seasonal fluctuation $(\mathrm{p}<0.001)$, with highest values occurring during the rainy season $($ mean $=95.7 \pm 16.8 \mathrm{mM})$.

High values of algal biomass (chlorophyll- $a . \mathrm{L}^{-1}$ ) were recorded $\left(8.7 \pm 12.0 \mathrm{mg} . \mathrm{L}^{-1}\right)$, and their seasonal concentrations were significantly different $(p<0.001)$. They were higher in the rainy season $\left(13.8 \pm 10.1 \mathrm{mg} . \mathrm{L}^{-1}\right)$ than in the dry season $\left(3.6 \pm 4.7 \mathrm{mg} . \mathrm{L}^{-1}\right)$. According to the spatial variation in algal biomass, in both seasons the inner parts of the lagoon, shallower and more influenced by the Rio Jacú (P3 and P4), showed the highest values, and the maximum was always recorded at P4. Considering the concentrations of chlorophyll- $a$ and the trophic-state classification proposed by the EPA (2003) for coastal marine regions, the points that showed an oligotrophic state were P1 and P2 (Chl- $a<2$ mg.L $\mathrm{L}^{-1}$ ); localities classified as eutrophic (chlorophyll- $a>7$ mg. $\mathrm{L}^{-1}$ ) were $\mathrm{P} 3$ in the rainy season, and $\mathrm{P} 4$ in both seasons. There were also points of hypereutrophy, with peaks of chlorophyll- $a$ concentration above $25 \mathrm{mg} . \mathrm{L}^{-1}$, as recorded at P3 and P4 during the rainy season.

\subsection{Mesozooplankton}

Altogether 46 mesozooplankton taxa were identified in the Guaraíras Lagoon (Table 1). Holoplanktonic forms dominated the assemblages ( $80 \%)$. The mean total density of organisms was $18,300 \pm 870$ ind $\mathrm{m}^{-3}$. The spatial distribution of mesozooplankton density showed a marked spatial gradient, with the highest values at the sampling points which were most influenced by the adjacent marine region (P1 and P2) (Figure 3). Mesozooplankton abundance also showed a spatial-seasonal gradient, with the highest values observed in the coastal area of the lagoon during the rainy season (P1 and P2), while in the inner part of the lagoon (P3 and P4), the highest values occurred during the dry season. The relative importance of different taxa varied among stations, although copepods were by far the most important group in terms of species richness and

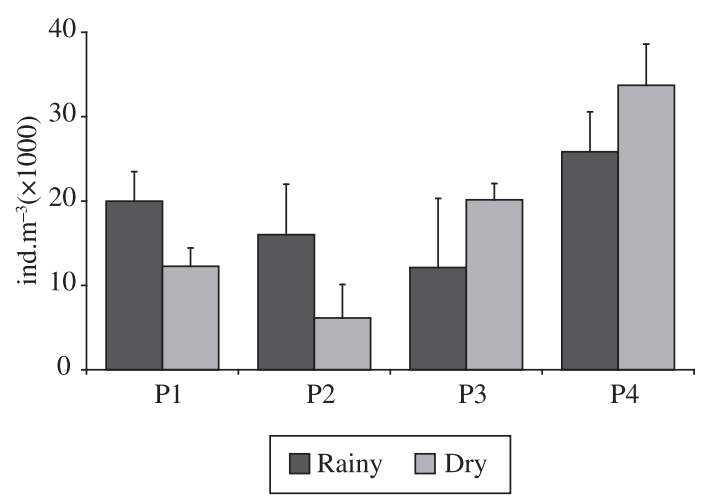

Figure 3. Spatial and temporal variation of mean (mean $\pm \mathrm{SD}$ ) concentration of mesozooplankton density (ind. $\mathrm{m}^{-3}$ ). abundance. In general, copepods were abundant in all the sampling points ( $>60 \%$ of relative abundance), and reached the greater of the total mesozooplankton $(80 \%)$ at P1 and P2 (rainy season) (Figure 4).

Eleven meroplankton groups were identified in the mesozooplankton of Guaraíras, including larvae of Gastropoda and Pelecypoda, Cirripedia, Brachyura and Polychaeta. The most abundant meroplanktonic morphotypes were Gastropoda (maximum of 1,630 ind. $\mathrm{m}^{-3}$ ), Pelecypoda $\left(4,630\right.$ ind. $\left.\mathrm{m}^{-3}\right)$ and Polychaete larvae (4,22 ind. $\left.\mathrm{m}^{-3}\right)$. Larvae of Pelecypoda, which represented a substantial fraction of mesozooplankton community in the lagoon, did not occur in P3 and P4 (rainy period), suggesting that salinity seems to be a crucial factor controlling their repartition in the lagoon.

There were 24 species of Copepoda in Guaraíras Lagoon, including unidentified monstrilloids and harpacticoids. The most abundant species were Oithona spp. (Oithona oswaldocruzi and O. hebes), Parvocalanus crassirostris, Paracalanus quasimodo and Acartia lilljeborgii. The copepod density was high, with mean values of $15,900 \pm 7,010$ ind $\mathrm{m}^{-3}$. The greatest spatial differentiation of copepod abundance occurred during the dry season, with a maximum of $27,700 \pm 5,400$ ind. $\mathrm{m}^{-3}$ in the inner area of the lagoon (P4) and a minimum of 5,700 $\pm 4,000$ ind. $^{-3}$ in the outer part of the lagoon (P2). Four copepod genera comprised more than $80 \%$ of the total mesozooplankton: Oithona, Acartia, Paracalanus and Parvocalanus. The genus Oithona (including $O$. oswaldocruzi and $O$. hebes) was the most abundant $\left(98 \pm 56\right.$ ind $\mathrm{m}^{-3}$ ), always exceeding $30 \%$ of the total mesozooplankton and reaching a maximum abundance $(67.4 \%)$ at P3 (rainy season). Paracalanus quasimodo and Parvocalanus crassirostris comprised more than $15 \%$ of the total mesozooplankton $\left(29 \pm 10\right.$ ind. $\left.\mathrm{m}^{-3}\right)$. Two exotic calanoid copepod species were recorded: Temora turbinata and Pseudodiaptomus trihamatus. Temora turbinata occurred during the entire study period, and reached appreciable densities in the lagoon (from 40 to 1,080 ind. $\mathrm{m}^{-3}$ ), exceeding in abundance the congeneric native species T. stylifera. Pseudodiaptomus trihamatus showed a more restricted distribution, occurring only during the dry season and remaining in low densities at all sampling points (10 ind. $\mathrm{m}^{-3}$ ).

The Shannon-Wiener diversity value ( $\mathrm{H}^{\prime}$ ) for copepods was extremely low, ranging from 1.22 to 0.46 . The evenness index ( $\mathrm{J}$ ) was also low (from 0.37 to 0.48 ), indicating the supremacy of only a few species in the quantitative pattern of copepod composition (Table 1).

\subsection{Multidimensional scaling analysis}

In the two-dimensional plot, a stress of 0.02 was obtained for the sampling points. According to Kibirige et al. (2006), stress levels $<0.05$ give an excellent representation of the similarities and provide confidence in the two-dimensional representation of the similarities. The results of the twodimensional plots of sampling points revealed the presence of two groups in the lagoon (Figure 5), regardless of the seasonal periods. Group I comprised those stations located in the upper part of Guaraíras Lagoon (P1 and P2), where coastal/ neritic copepod species such as Paracalanus quasimodo, 


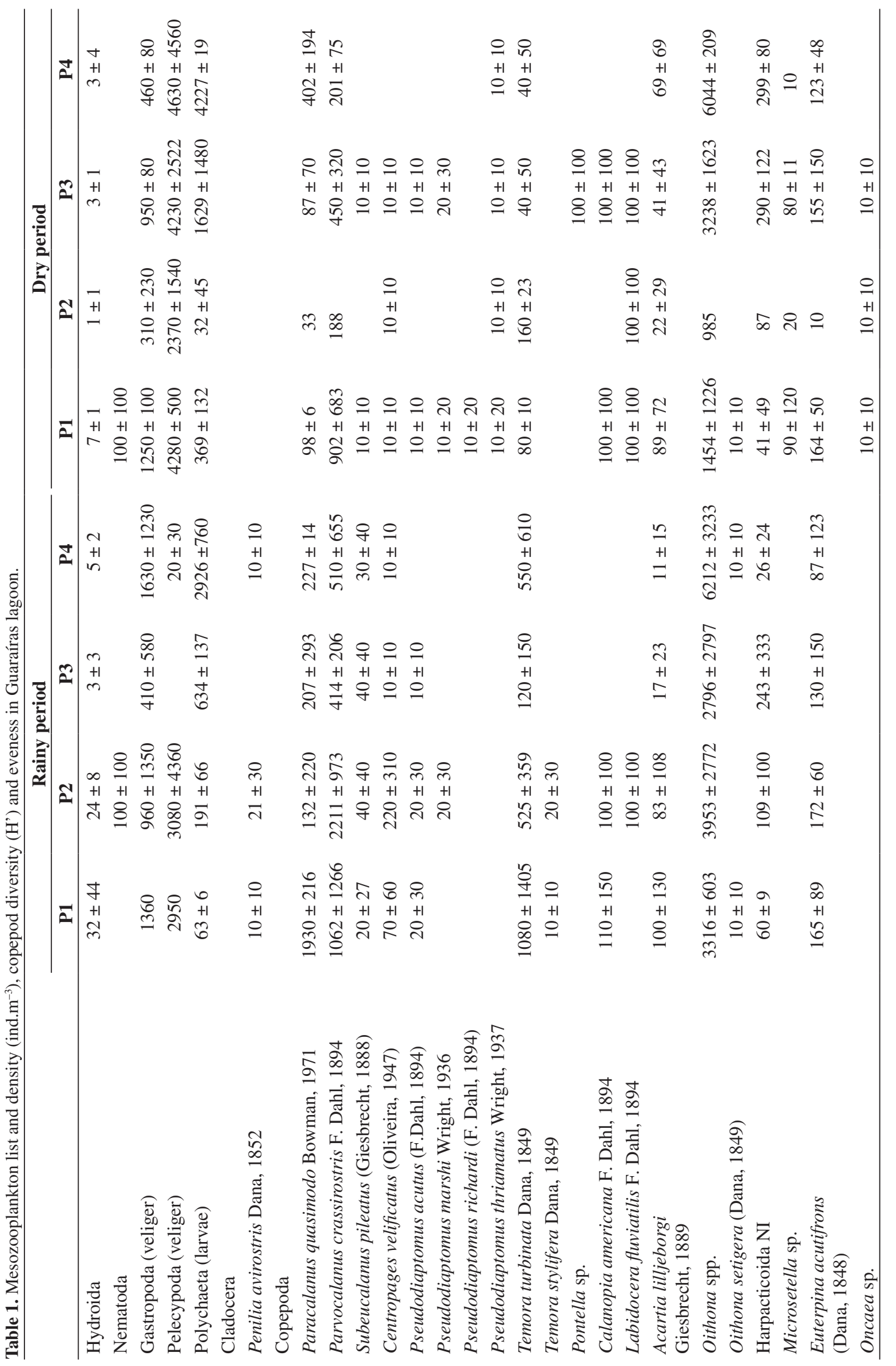




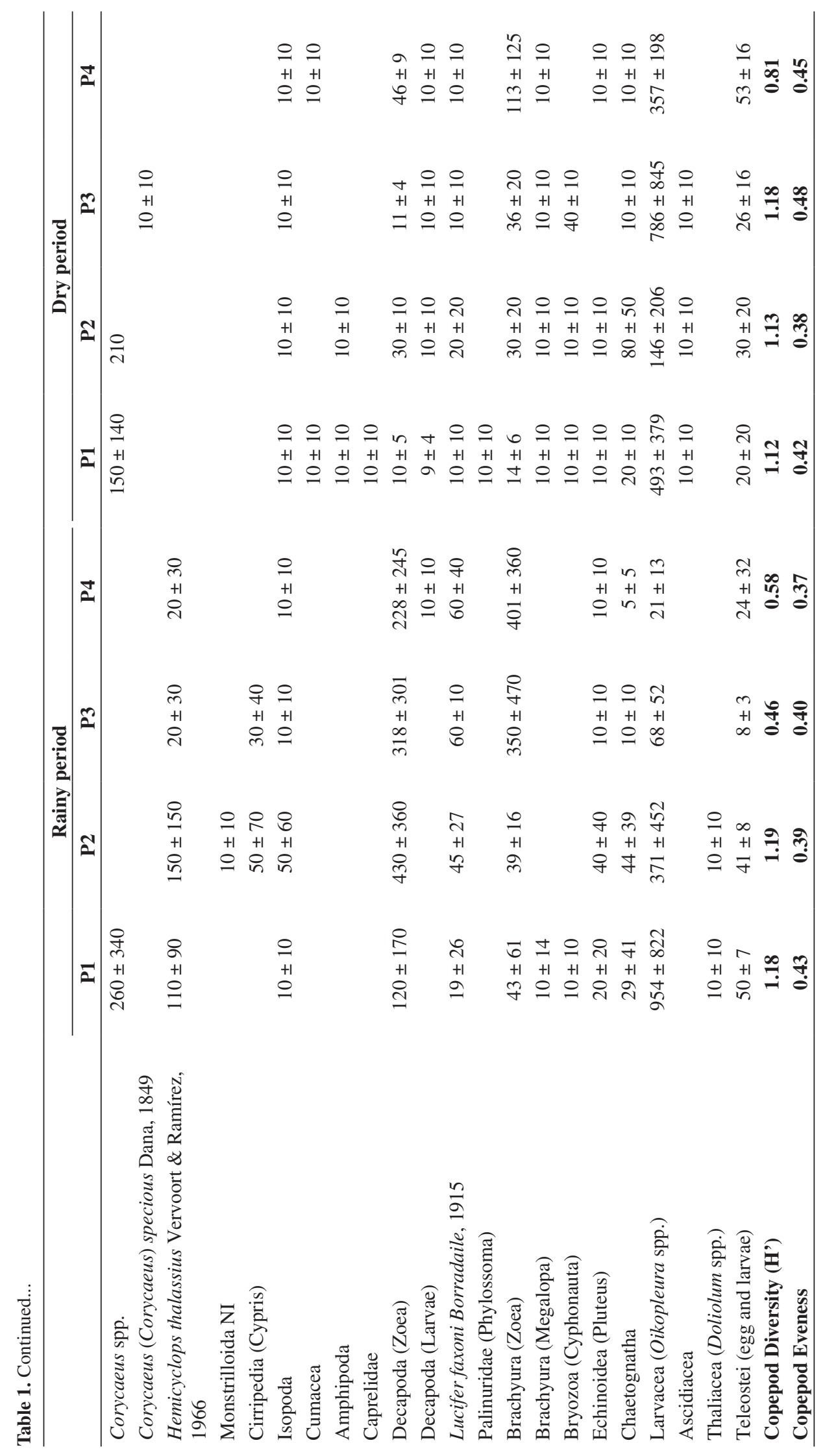




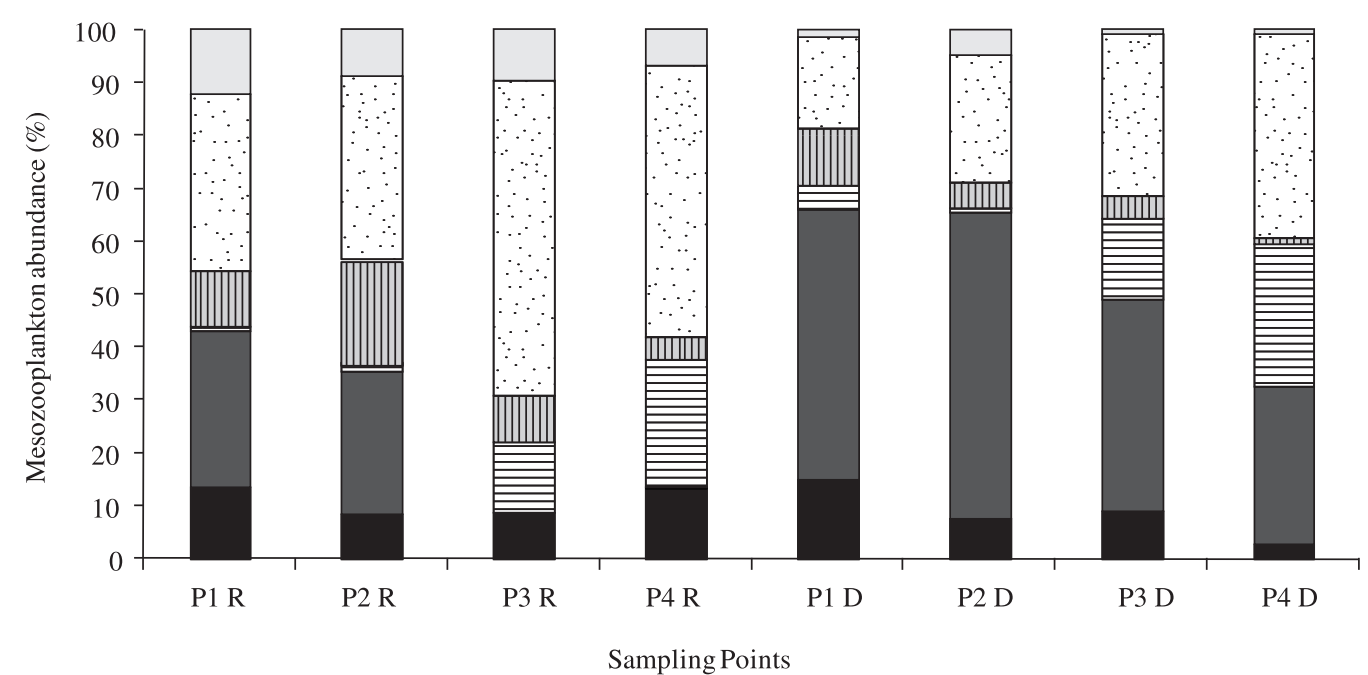

$\begin{array}{ll}\square \text { Gastropoda (Larvae) } & \square \text { Pelecypoda (Larvae) } \\ \boxminus \text { Polychaeta (Larvae) } & \square \text { Parvocalanus crassirostris } \\ \square \text { Oithona spp. } & \square \text { Others }\end{array}$

Figure 4. Mesozooplankton composition and abundance (\%) in Guaraíras lagoon.
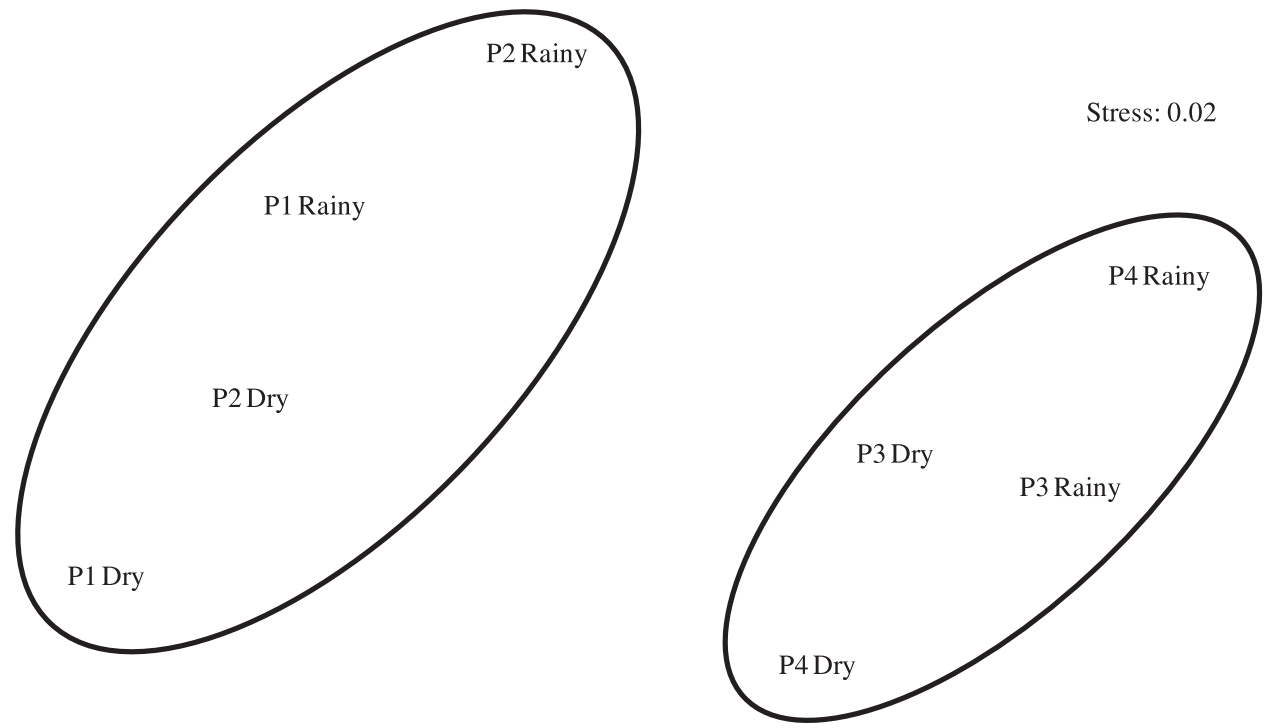

Figure 5. MDS two-dimensional ordination plots of sampling points and seasonal periods.

Calanopia americana, Corycaeus (C.) speciosus and monstrilloids occurred, and salinity averaged $34.3 \pm 4.8$. Group II was represented by the sampling points located in the inner and middle parts of the lagoon (P3 and P4), characterized by coastal/estuarine copepod assemblages represented by Oithona spp., Acartia lilljeborgii and Parvocalanus crassirostris; salinity averaged $24 \pm 11.31$.

\subsection{Principal components analysis}

The relationship between the copepod assemblages and environmental variables is revealed in the PCA results (Figure 6). The first two components explained $66.5 \%$ of the variability. Component I was associated with chlorophyll- $a$ and total phosphorus, indicating a relationship with organic enriched waters, likely representing the influence of cultural eutrophication on the lagoon. Component II was associated with temperature and salinity, and represents the influence of coastal waters in the area. The negative quadrant of factor 1 shows the copepod taxa such as $P$. quasimodo, $P$. crassirostris and $T$. turbinata, which occur mainly in areas influenced by high salinity. The positive side of factor 2 includes copepods of the genus Oithona spp., Acartia lilljeborgii, and Polychaeta larvae, Gastropoda and Pelecypoda larvae. The occurrence of these taxa 


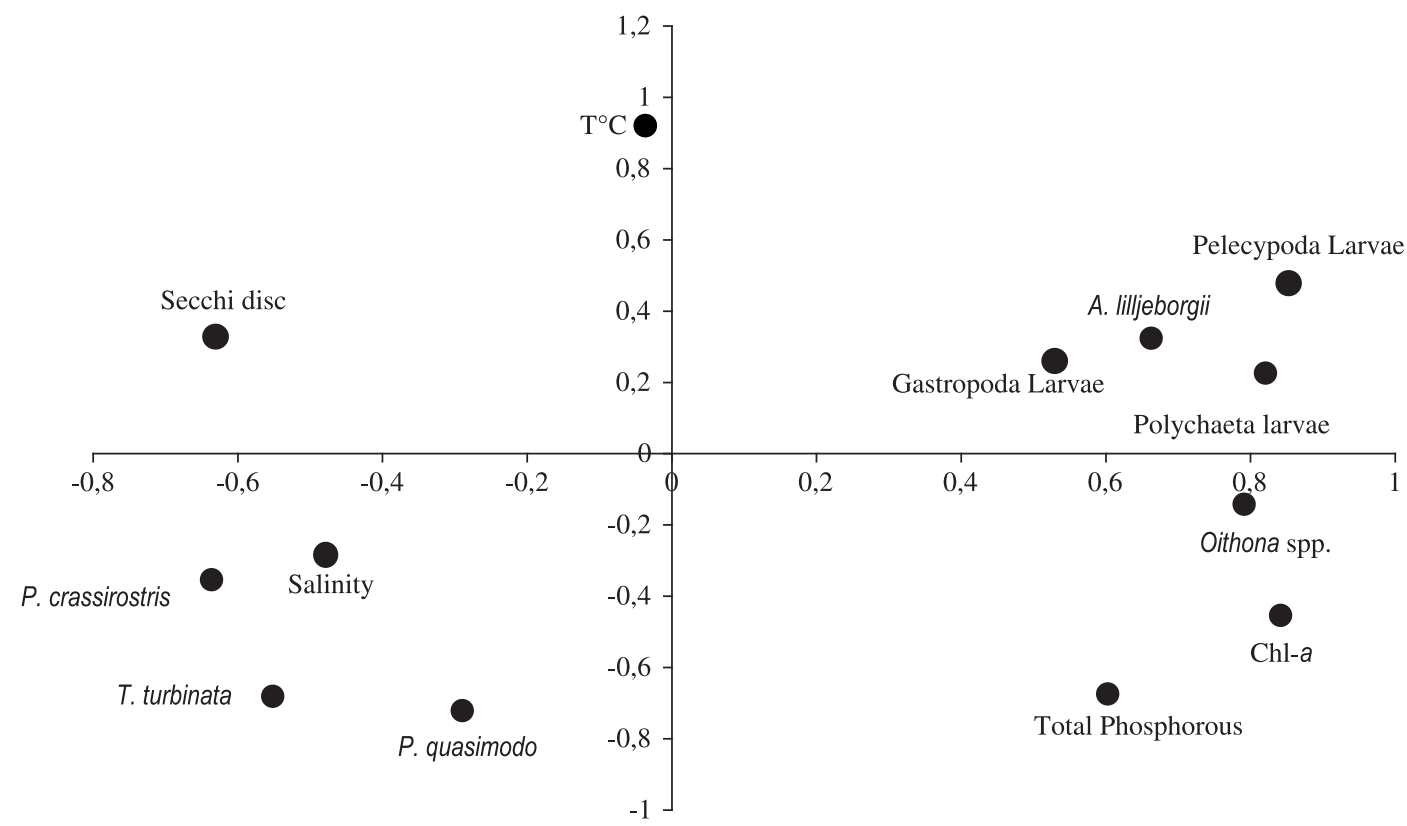

Figure 6. Two-dimensional plot of mesozoplankton and abiotic variables from the two Principal Componentes of the PCA.

was usually associated with high concentrations of algal biomass (chlorophyll- $a$ ) and total phosphorus.

\section{Discussion}

The spatial differences observed in the water physicochemical patterns of the Guaraíras Lagoon indicate that physical events (water exchange and tidal currents) play an important role in causing the marked spatial salinity gradient and trophic state of this ecosystem. As expected, the salinity gradient in Guaraíras results from freshwater inflow from the Jacú River in the inner area, and extensive mixing between the middle and marine areas. Reef breakup increased the inflow of marine water and, in addition to reducing the river contribution, contributed to the occurrence of marine-coastal, rather than truly estuarine conditions in the lagoon.

Water circulation and residence times in coastal lagoons are regulated by tidal cycles, morphology, and freshwater inputs, and therefore structures that modify water flow or affect the fresh-marine water balance, affect the hydrodynamics in these types of ecosystems, impacting their water quality (González et al., 2008). According to Lacerda et al. (2006), the wide tidal amplitude and the low altitude gradient of the coastal basins of the rivers of the Brazilian Northeast makes its estuaries very sensitive to variations in sea level and changes in river flow, generally increasing saline intrusion into the continent. This process is generally caused by the geomorphological changes that contribute to sedimentation in mangrove areas and salinization of the estuaries, such as damming of the rivers. The extensive reservoirs that have been constructed in the northeastern region (which regulate about $90 \%$ of the river flow), reduce the volume of fresh water that reaches the estuaries, and decisively affect the salinity patterns of these transitional waters, an observable fact occurring in the hydrographic basin of the Guaraíras lagoon.

Coastal lakes can also reach high salinities because of the long water retention time and intense evaporation (Valiela et al., 1992). However, Guaraíras Lagoon has a highly dynamic tidal pattern, characterized by strong currents of marine inflow and outflow, which exposes the sediment in the shallower inner parts. Therefore, the high salinity observed in the lagoon reflects the strong influence of the coastal water mass.

In tropical waters, seasonal variations are more difficult to determine than in temperate waters, and are normally less significant. They are generally related to the annual rainfall patterns, especially in coastal regions (Chisholm and Roff, 1990). Although rainfall is seasonal in this area, these seasonal differences did not reduce the mean salinity concentration in the lagoon, which remained quite high. According to the estuary zonation system based on salinity (Gibson et al., 2000), Guaraíras Lagoon is presently euhaline (>30), typical of the marine areas of estuarine systems.

According to Dame and Allen (1996), in shallow lagoon and estuarine systems, with little freshwater inflow, transport of suspended particulate matter is frequently governed by the tide. This strong influence of the adjacent marine area was observed in sedimentological studies in the lagoon (Bentes, 2006), showing that marine sedimentation prevails over riverine, with sand sediments occurring near the mouth of the lagoon, where stronger currents were recorded. In the area near the Rio Jacú, the organic-matter content is higher because the influence of inflow and outflow is less. These characteristics make the inner area of Guaraíras Lagoon extremely vulnerable to eutrophication and algal blooms. 
The permanent agribusiness activities in the watershed of Guaraíras Lagoon may also contribute to the spatial differentiation of the degree of trophy, as well as influence the present ecological status of the lagoon, because of the high input of allochthonous organic matter and nutrients in the upper freshwater tidal lagoon. While estuarine and coastal marine systems can often be hydrologically and spatially complex, the biomass of phytoplankton in these systems nonetheless tends to respond predictably to changes in the water column concentrations of total nitrogen and total phosphorus (Smith, 2006). The excess loading of nutrients into the Guaraíras lagoon appear to be converted to elevated algal biomass, as observed by chlorophyll- $a$ concentration gradients, which showed high values, in relation to other tropical and temperate enriched estuarine systems (Herrera-Silveira, 1995; van Damme et al., 2005).

Lack of data makes it difficult to estimate the impact of geomorphological changes on the composition, distribution and abundance of mesozooplankton in the lagoon. However, the spatial differences in the copepod assemblages were closely related to the marine intrusion.

The mesozooplankton was dominated by Copepoda, which made up nearly $80 \%$ of total abundance and showed low diversity. The composition of the mesozooplankton community is characteristic of tropical coastal lagoons (Lopes, 1994; Neumann-Leitão et al., 1992), in which cyclopoid copepods of the genus Oithona predominate. Species of Oithona are frequently among the dominant copepods in low-salinity waters of Brazilian estuaries (Neumann-Leitão and Matsumura-Tundisi, 1998) and are favored in extreme environments such as estuaries, because of their extraordinary ecological plasticity. According to Calbet et al. (2000), copepods of the genus Oithona can efficiently ingest relatively small particles, including nanophytoplankton, and also large cells (>50 mm), which can favor the dominance of these copepods in eutrophic conditions. All these characteristics demonstrate that this genus is highly adapted to environmental conditions of high primary productivity, low transparency, and high concentrations of suspended particulate matter, which are common in eutrophic systems, which makes this genus a potential bioindicator of eutrophic conditions, as indicated by the PCA analysis.

The tidal inflow into the lagoon, which increased after the barrier was breached, carries marine species such as Paracalanus quasimodo, $P$. indicus, Calanopia americana, Oncaea venusta, Corycaeus (C.) speciosus and Microsetella rosea, leading to spatial heterogeneity in the mesozooplankton composition. The results of the MDS analysis suggest that the copepod population in the lagoon changes progressively from an estuarine- to a marinedominated assemblage along a salinity gradient, without an abrupt transition zone between the inner-riverine part and the outer-marine part of the lagoon.

Reef breakup could increase the tidal inflow and favor the exchange of zooplankton from the adjacent coastal waters to the inner areas of coastal lagoons, promoting coexistence between estuarine and marine-coastal species, and thus increasing the local biological diversity. However, the low copepod diversity observed in the lagoon, as demonstrated by the Shannon index, indicated that only euryhaline copepod species such as Parvocalanus crassirostris, Oithona spp. and Acartia lilljeborgii reached high densities, reducing local diversity, as also observed by Casé et al. (2008), in hypereutrophic coastal systems.

The presence of exotic copepods species in the lagoon emphasizes the extreme vulnerability of coastal systems to bioinvasions. Temora turbinata has been widely reported from other estuaries on the coast of Brazil, where it has numerically supplanted the native congener T. stylifera. Pseudodiaptomus trihamatus is a planktonic brackishwater species of Southeast Asian origin, which has been recorded in some coastal systems of Rio Grande do Norte (Medeiros et al., 2006). In the present study, specimens of $P$. trihamatus were recorded in the Guaraíras Lagoon in low densities $\left(<10\right.$ ind. $\left.\mathrm{m}^{-3}\right)$, but females with egg sacs were observed, an indication of the acclimatization of the species and its establishment in the region.

Estuarine systems support many important ecosystem functions: biogeochemical cycling and movement of nutrients, purification of water, mitigation of floods, maintenance of biodiversity, biological production (nursery grounds for many commercial fish and crustacean species) (Day et al., 1989). An estimate of the economic value of these ecosystem functions indicated that estuaries are among the most valuable ecosystems in the world and serve as important life-support also for human beings (Costanza et al., 1997). Shifts in the ecological configuration and the present ecological status observed in the Guaraíras Lagoon may represent the loss of valuable functions, such as a nursery grounds for various commercial fish and crustacean species, as shown by the low abundance of meroplanktonic larvae detected in the lagoon.

The high input of allochthonous organic matter and nutrients in the upper freshwater lagoon and unfavorable conditions, i.e., high temperatures, shallowness and low river flows, are key factors that contribute to the spatial variation in the trophic degree of the lagoon. The permanence of meso-eutrophic conditions of the water may be decisively affected by the intensive shrimp aquaculture in the surrounding watershed. Special attention must be given to temporal and spatial changes in the trophic degree of the lagoon, which may result in eutrophication and the development of cyanobacterial populations. Considering the development of aquaculture and fisheries activities in the Guaraíras lagoon, this is a perspective that must be continuously monitored. The constant exchange of waters with the adjacent ocean may be, at the present time, the best guarantee to reduce or even prevent eutrophication in Guaraíras Lagoon.

Acknowledgements - We acknowledge Francisco Aparecido (Dido) for his help in the sample collection and experience during the navigation in the area. We would also like to thank the National Council for Scientific and Technological Development $(\mathrm{CNPq})$ for the financial support for this study and to Janet Reid for her careful revision of English. 


\section{References}

BENTES, MCG., 2006. Estudo dos sedimentos de fundo do sistema estuarino lagunar Nísia Floresta-Papeba-Guaraíras. Natal: Universidade Federal do Rio Grande do Norte. 95 p. Dissertação de Mestrado em Engenharia Sanitária.

BUSKEY, EJ., 1993. Annual pattern of micro- and mesozooplankton abundance and biomass in a subtropical estuary. Journal of Plankton Research, vol. 8, p. 907-924.

CALBET, A., LANDRY, MR. and SCHEINBERG, RD., 2000. Copepod grazing in a subtropical bay: species-specific responses to a midsummer increase in nanoplankton standing stock. Marine Ecology Progress Series, vol. 193, p. 75-84. http://dx.doi. org/10.3354/meps193075

CASÉ, M., ESKINAZI-LEÇA, E., NEUMANN-LEITÃO, S., ESKINAZI-SANT'ANNA, EM., SCHWAMBORN, R. and MORAES JÚNIOR, AT., 2008. Plankton community as an indicador of water quality in tropical shrimp ponds. Marine Pollution Bulletin, vol. 56, p. 1343-1352. PMid:18538353. http:// dx.doi.org/10.1016/j.marpolbul.2008.02.008

CHAMPALBERT, G., PAGANO, M., SENE, P. and CORBIN, D. 2007. Relationships between meso- and macro-zooplankton communities and hydrology in the Senegal River Estuary. Estuarine, Coastal and Shelf Science, vol. 74, p. 381-394. http:// dx.doi.org/10.1016/j.ecss.2007.04.023

CHISHOLM, LA. and ROFF, JC., 1990. Abundance, growth rates, and production of tropical neritic copepods off Kingston, Jamaica. Marine Biology, vol. 106, p. 79-89. http://dx.doi. org/10.1007/BF02114677

COSTANZA, R., DÁRGE, R., GROOT, R., FARBER, S., GRASSO, M., HANNON, B., LIMBURG, K., NAEEM, S., O'NEILL, RV., PARUELO, J., RASKIN, RG., SUTTON, PM. and Van Den BELT., D., 1997. The value of the world's ecosystem services and natural capital. Nature, vol. 387, p. 253-260. http:// dx.doi.org/10.1038/387253a0

DAME, RF. and ALLEN, DM., 1996. Between estuaries and the sea. Journal of Experimental Marine Biology and Ecology, vol. 200, p. 169-185. http://dx.doi.org/10.1016/S0022-0981(96)02642-1

DAY, JR., HALL, CAS., KEMP, WM. and YÁÑEZ-ARANCIBIA, A., 1989. Estuarine Ecology. London: John wiley \& Sons. 558 p.

GIBSON, GR., BOWMAN, ML., GERRITSEN, J. and SNYDER, BD., 2000. Estuarine and coastal marine waters: Bioassessment and biocritera technical guidance. Washington: EPA. 234 p.

GONZÁLEZ, FUT., HERRERA SILVEIRA, JA. and AGUIRREMACEDO, ML., 2008. Water quality variability and eutrophic trends in karstic tropical coastal lagoons of the Yucatán Peninsula. Estuarine, Coastal and Shelf Science, vol. 76, p. 418-430.

HERRERA-SILVEIRA, JA. and COMÍN, FA., 1995. Nutrient fluxes in a tropical coastal lagoon. Ophelia, vol. 42, p. 127-146.

HOLM-HANSEN, O., LORENZEN, CJ., HORMES, RN. and STRICKLAND, JDH., 1965. Fluorometric determination of chlorophyll. Journal du Conseil / Conseil Permanent International pour l'Exploration de la Mer, vol. 30, p. 3-15.

KIBIRIGE, I., PERISSINOTTO, R and THWALA, X., 2006. A comparative study of zooplankton dynamics in two subtropical temporarily open/closed estuaries, South Africa. Marine Biology, vol. 148, p. 1307-1324. http://dx.doi.org/10.1007/s00227-005-0175-2
KJERFVE, B. and MAGILL, KE., 1989. Geografical and hydrographic characteristics of shallow coastal lagoons. Marine Biology, vol. 88, p. 187-199.

LACERDA, LD., VAISMAN, AG., MAIA, LP., SILVA, CAR. and CUNHA, EMS., 2006. Relative importance of nitrogen and phosphorous emissions from shrimp farming and other anthropogenic sources for six estuaries along the NE Brazilian coast. Aquaculture, vol. 253, p. 433-446. http://dx.doi.org/10.1016/j. aquaculture.2005.09.005

LEANDRO, SM., MORGADO, F., PEREIRA, F. and QUEIROGA, H., 2007. Temporal changes of abundance, biomass and production of copepod community in a shallow temperate estuary (Ria de Aveiro, Portugal). Estuarine, Coastal and Shelf Science, vol. 74, p. 215-222. http://dx.doi.org/10.1016/j.ecss.2007.04.009

LLORET, J., MARÍN, A and MARÍN-GUIRAO, L., 2008. Is coastal lagoon eutrophication likely to be aggravated by global climate change? Estuarine, Coastal and Shelf Science, vol. 78, p. 403-412. http://dx.doi.org/10.1016/j.ecss.2008.01.003

LOPES, RM., 1994. Zooplankton distribution in the Guaraú river estuary (South-eastern Brazil). Estuarine, Coastal and Shelf Science, vol. 39, p. 287-302. http://dx.doi.org/10.1006/ecss.1994.1065

LOPES, RM, do VALE, R. and BRANDINI, FP., 1998. Composição, abundância e distribuição espacial do zooplâncton no complexo estuarino de Paranaguá durante o inverno de 1993 e o verão de 1994. Revista Brasileira de Oceanografia, vol. 46, p. 195-211.

McLUSKY, DS. and ELLIOT, M., 2004. The Estuarine Ecosystem: Ecology, Threats and Management. Oxford: Oxford University Press. 214 p.

MEDEIROS, GF., MEDEIROS, LS., HENRIQUES, DMF., LIMA, MT., FAUSTINO, GVBS. and LOPES, RM., 2006. Current distribution of the exotic copepod Pseudodiaptomus trihamatus, Wright, 1937, along the northeastern coast of Brazil. Brazilian Journal of Oceanography, vol. 54, p. 241-245. http:// dx.doi.org/10.1590/S1679-87592006000300008

MEIRE, P., YSEBAERT, T., Van DAMMEI, S., Van Den BERGH, E., MARIS, E. and STRUYF, D., 2005. The Scheldt estuary: a description of a changing ecosystem. Hydrobiologia, vol. 540, p. 1-11. http://dx.doi.org/10.1007/s10750-005-0896-8

MORENO, M., FERRERO, TJ., GALLIZIA, I., VEZZUULLI, L., ALBERTELLI, G. and FABIANO, M., 2008. An assessment of the spatial heterogeneity of environmental disturbance within an enclosed harbour through the analysis of meiofauna and nematode assemblages. Estuarine, Coastal and Shelf Science, vol. 77, p. 565-576. http://dx.doi.org/10.1016/j.ecss.2007.10.016

NEUMANN-LEITÃO, S. and MATSUMURA-TUNDISI, T., 1998. Dynamics of a perturbed estuarine zooplanktonic community: Porto of Suape, PE, Brazil. Verhandlungen des Internationalen Verein Limnologie, vol. 26, p. 1981-1988.

NEUMANN-LEITÃO, S., PARANAGUÁ, MN. and VALENTIM, JL., 1992. Ecology of planktonic Rotifera of the estuarine lagunar complex at Suape, Pernambuco (Brazil). Hydrobiologia, vol. 232, p. 133-143.

SHANNON, CE., 1948. A mathematical theory of communication. Bell System Technical Journal, vol. 27, p. 379-423.

SMITH, VH. 2006. Responses of estuarine and coastal marine phytoplankton to nitrogrn and phosphorous enrichment. Limnology \& Oceanography, vol. 51, p. 377-384. http://dx.doi.org/10.4319/ lo.2006.51.1_part_2.0377 
United States Environmental Protection Agency - EPA, 2003. Phytoplankton community structure as an indicator of coastal ecosystem health. University of North Carolina at Chapel Hill. 234 p. Annual Report.

VALDERRAMA, JC., 1995. Methods of Nutrient Analysis. In: HALLEGRAEFF, GH., ANDERSON, DM. and CEMBELLA, AB. (Eds.). Harmful Marine Microalgae. UNESCO. 324 p. IOC Manuals and Guides.

VALIELA, I., FOREMAN, K., LAMONTAGNE, M, and HERSH, DD., 1992. Coupling of watersheds and coastal waters: sources and consequences of nutrient enrichment in Waquoit
Bay, Massachusetts. Estuaries, vol. 15, p. 443-457. http://dx.doi. org/10.2307/1352389

van DAMME, S., STRUYF, E., MARIS, T., YSEBAERT, T., DEHAIRS, F., TACKX, M., HEIP, C. and MEIRE, P., 2005. Spatial and temporal patterns of water quality along the estuarine salinity gradient of the Scheldt estuary (Belgium and The Netherlands): results of an integrated monitoring approach. Hydrobiologia, vol. 540, p. 29-45. http://dx.doi.org/10.1007/s10750-004-7102-2

WEBBBER, MK. and ROFF, JC., 1995. Annual biomass and production of the oceanic copepod community off Discovery Bay, Jamaica. Marine Biology, vol. 123, p.481-495. 